\title{
SPINE GUNSHOT WOUNDS AT THE CENTRAL MILITARY HOSPITAL IN MEXICO
}

\author{
FERIDAS POR PROJÉTIL DE ARMA DE FOGO NA COLUNA VERTEBRAL NO HOSPITAL \\ CENTRAL MILITAR DE MÉXICO
}

\section{HERIDAS POR PROYECTIL DE ARMA DE FUEGO EN LA COLUMNA VERTEBRAL EN EL HOSPITAL CENTRAL MILITAR DE MÉXICO}

Isaac Enrique Hernández Téllez ${ }^{1}$, Edgardo Alonso Montelongo Mercado ${ }^{1}$, Jesús José Arreola Bastidas',

Eduardo Larrinúa Betancourt ${ }^{1}$, Avelino Aguilar Merlo

1. Hospital Central Militar, Departamento de Ortopedia y Traumatología, Ciudad de México, D.F., México

\begin{abstract}
Objective: To compare the measurement of the Cobb angle in printed radiographs and digitalized radiographs displayed with the "PixViewer" tool. Methods: Pre-operative radiographs of 23 patients were performed in printed films and using the software "PixViewer". The same evaluator, a spine surgeon, chose the proximal and distal end vertebrae at the limit of the main curve in printed radiographs without identifying patients, and measured the Cobb angle based on these parameters. The same parameters and measurements were performed in digitalized radiographs. The measurements were compared, as well as the choice of end vertebrae. Results: The average change in the Cobb angle between the methods was $1.48 \pm 1.73^{\circ}$. The intraclass correlation coefficient (ICC) was 0.99 , demonstrating excellent reproducibility. Conclusion: The Cobb method can be used to evaluate scoliosis through the "PixViewer" tool with the same reliability of the classic method on printed radiographs.
\end{abstract}

Keywords: Scoliosis; Spinal diseases; Spinal curvatures; Radiographic image enhancement.

\section{RESUMO}

Objetivo: Comparar a aferição do ângulo de Cobb em radiografias impressas e em radiografias digitalizadas visualizadas com a ferramenta "PixViewer". Métodos: Foram avaliadas as radiografias pré-operatórias de 23 pacientes em filmes impressos e com o software "PixViewer". O mesmo avaliador, cirurgião da coluna, elegeu a vértebra limite proximal e distal da curva principal nas radiografias impressas, sem identificação dos pacientes, e realizou a aferição do ângulo de Cobb baseado nesses parâmetros. Os mesmos parâmetros e aferições foram realizados nas radiografias digitalizadas. As aferições foram comparadas, assim como a escolha das vértebras limite. Resultados: A variação média do ângulo de Cobb entre os métodos foi de 1,48 $\pm 1,73^{\circ}$. O coeficiente de correlação intraclasse (CCl) foi de 0,99, demonstrando replicabilidade excelente. Conclusão: O método de Cobb pode ser utilizado para avaliação da escoliose com a ferramenta "PixViewer" com a mesma confiabilidade que através do método clássico em radiografias impressas.

Descritores: Escoliose; Doença da coluna vertebral; Curvaturas da coluna vertebral; Intensificação de imagem radiográfica.

\section{RESUMEN}

Objetivo: Comparar la medición del ángulo de Cobb en radiografías impresas y en radiografías digitalizadas visualizadas con la herramienta "PixViewer". Métodos: Se evaluaron las radiografías preoperatorias de 23 pacientes en películas impresas e con el software "PixViewer". El mismo evaluador, cirujano de columna, eligió la vértebra límite proximal y distal de la curva principal en las radiografías impresas, sin identificar a los pacientes, y se realizó la medición del ángulo de Cobb con base en estos parámetros. Los mismos parámetros y mediciones se realizaron en las radiografías digitalizadas. Las mediciones fueron comparadas, así como la elección de las vértebras límite. Resultados: La media del cambio en el ángulo de Cobb entre los métodos fue de 1,48 $\pm 1,73^{\circ}$. El coeficiente de correlación intraclase (CCl) fue de 0,99, demostrando excelente reproducibilidad. Conclusión: El método de Cobb puede ser utilizado para evaluación de la escoliosis con la herramienta "PixViewer" con la misma fiabilidad del método clásico con radiografías impresas.

Descriptores: Escoliosis; Enfermedades de la columna vertebral; Curvaturas de la columna vertebral; Intensificación de imagen radiográfica.

\section{INTRODUCTION}

Gunshot wounds are lesions of a blunt nature caused by bullets or projectiles fired from a gun and from concurrent elements plus neo-elements formed at the time of the shooting. A wound is defined as a break in the continuity of the tissues of the human body resulting from trauma. Firearms are defined as instruments in various forms intended to launch projectiles using the forces of gases released when the gunpowder is ignited.

Each year in the United States of North America, approximately 30,000 to 50,000 people die from causes secondary to gunshot wounds, the greatest number of deaths occurring in the 1 to 19 years of age group. Additionally, it is estimated that for each death there are at least three disabling wounds. This translates to approximately 150,000 gunshot wounds per year. ${ }^{1}$ In the same country, violence with firearms, regardless of the medical implications, has a high 
economic impact as the third most costly etiology and the fourth most common cause of hospitalization. ${ }^{1}$

The primary objective of the initial evaluation should be directed towards the identification of life-threatening lesions that compromise maintenance of the airways, breathing, and circulation (the $\mathrm{ABC}$ of trauma) and later, once the patient is stable, to request the proper imaging studies to assist decision making about the management of spine lesions. In the specific case of gun wounds, the type of firearm used must be researched, the number of shots received by the victim, the range from which the shots were fired, and the trajectory inside the human body all offer important information to guide us in analyzing the organs and structures that may have been injured, as well as to determine the entry and exit points of the projectile. ${ }^{1}$

The two most common types of medullary lesions from wounds are, in first place, those caused by firearm projectiles and, less frequently, in second place those from sharp pointed weapons. ${ }^{1}$ The bodily damage from a firearm wound is explained as follows: kinetic energy ( $E=1-2 \mathrm{mv}$ ) , i.e., the energy produced by the continuous movement of the projectile is calculated from its mass and the velocity at which it is fired. Mass is defined as the weight of the bullet, which on average is between 2 and 10 grams (the point) and the velocity is measured in meters/second. Projectiles can be divided into low velocity, with less than $304 \mathrm{~m} / \mathrm{s}$, intermediate velocity up to $600 \mathrm{~m} / \mathrm{s}$, and high velocity above $600 \mathrm{~m} / \mathrm{s}$. A minimum velocity of $70 \mathrm{~m} / \mathrm{s}$ is required for a firearm projectile to penetrate the skin and a velocity of at least $100 \mathrm{~m} / \mathrm{s}$ to break a bone. ${ }^{1}$

Although fatal wounds related to firearms projectiles are unfortunate, trauma from firearm projectiles continues to be a significant cause of morbidity and socioeconomic cost with approximately 115,000 injuries and 40,000 deaths annually. ${ }^{1}$

The treatment of associated fractures is usually dictated by the bone lesions, which are similar to closed fractures. Because contamination of the wound is not always evident, routine prophylaxis with antibiotics is recommended. The soft tissues assume a much more important role in fractures from high-speed projectiles and shotguns, while wounds from high-energy projectiles and highly contaminated wounds require irrigation, proper tissue debridement, and the use of protocols for exposed fractures. However, a patient with a wound from a high-velocity projectile with limited disruption of the soft tissue, without significant functional deficit or evidence of fragmentation of the projectile, and minimal involvement of the bone tissue, may be a candidate for simple wound care. When surgical exploration is indicated, decompression and excision of the necrotic tissue is usually determined by criteria of color, consistency, contractility, and the ability to bleed, which provide valuable information in determining the viability of the muscle. ${ }^{2}$

Today, wounds from firearm projectiles account for approximately $13 \%$ of all causes of lesion of the spinal cord and/or the spine, increasing to $14 \%$ if penetrating wounds (knives, sharp pointed objects) are included. ${ }^{1,2}$ More than $60 \%$ of cases occur in patients between the 15 and 29 years of age and another $23 \%$ in patients from 30 to 34 years of age. ${ }^{2}$ The most frequently affected region is the chest at approximately $45 \%$, followed by the lumbar region at $30 \%$, and the cervical region at $25 \%{ }^{2}$ Gunshot wounds are the third most common cause of traumatic spine lesions, only slightly less that traffic accidents and very serious falls. ${ }^{2}$ Damage to the spinal cord may be primary, a direct consequence of the trauma, or secondary, occurring following the trauma as a result of a loss of medullary microcirculation, a loss of self-regulation, and medullary ischemia. ${ }^{2}$

Gunshot wounds to the spine commonly result in complete lesions. Some study series report $62 \%$ of cases with total paraplegia, while others suggest $29 \%$ with total paraplegia, $23 \%$ with incomplete paraparesis, and $19 \%$ with total quadraplegia. In some cases, an incomplete lesion can be produced that presents a deficit distal to the spinal cord but with the preservation of some functions. ${ }^{2}$

Plain anteroposterior and lateral radiographs at the level of the lesion should be requested or dynamic radiographs when there is structural spinal instability. Computed axial tomography is the imaging test of choice for these lesions because it permits the characteristics of the fracture and the location of the projectile to be determined and clearly shows the trajectory. Transverse images are usually suitable for making an adequate diagnosis. The use of magnetic resonance is controversial. It is very useful in evaluating the spinal cord and in cases of complete lesion of the spinal cord, but migration of the bullet can occur from the magnetic force and lead to greater damage to the nerves and the soft tissue. Its use should be individualized according to the specific needs of each patient. ${ }^{2}$

Surgical treatment of the spine is indicated when there is neurological damage with evidence of compression concordant with the level of the lesion, spine instability, or when the projectile is close to the nerve conduit. It should be taken into account that decompression and extraction of a projectile from level T12 and the lumbar levels because of neurological damage may result in motor improvement. Some cases of cervical lesions may improve when medullary lesions are incomplete. The worst neurological functional prognoses come from lesions of the thoracic spine. As regards the best time to perform decompression surgery, there has been no proof to date that performing it urgently (in less than 72 hours) results in a better outcome or a lower number of complications. ${ }^{2}$ Lesions of the thoracic spine produce the greatest number of firearms deaths, for which reason is paramount to assess damages to the heart, lungs, great vessels, abdomen, intestines, and solid organs, because these lesions are at high risk of infecting the spine if not properly treated with antibiotics. ${ }^{3}$

In the case of injury to the cervical spine, the airways, esophagus, and trachea should be evaluated in particular. In lesions of the lumbar spine, the evaluation should include the abdominal and pelvic organs, the large vessels, and the retroperitoneal region. In wounds of the sacral spine, the main injury to be ruled out is to the great vessels as they can produce bleeding. In a spinal cord lesion, it is important to determine the level of preservation of function of the nerve tracts in order to make therapeutic and prognostic recommendations. An injury can be considered incomplete when there is sensory or residual motor function below the anatomical lesion, perianal sensitivity, or sphincter control. An injury is considered to be complete when there is an absence of motor or sensory function below the anatomical lesion. ${ }^{3}$

Immobilization of the cervical spine is required for gunshot wounds, especially when there is a head and neck wound, a Glasgow coma scale score of less than 8 , neurological deficit, a change in mental state, and spinal cord involvement. ${ }^{4}$

The use of antibiotics is indicated in case of contaminated wounds. In exposed fractures, the use of antibiotics should be started as soon as possible and continued for three days (Gustillo I and II) and for a period of 5 days for type III fractures. ${ }^{5}$

Antibiotics are an important component of treatment and should be continued for a minimum of 7 days in cases of wounds that perforate the colon and injure the spine. Corticosteroids do not improve neurological outcomes and therefore should not be used. Decompression and the removal of intraforaminal bullets in T12 and below should improve motor function. Regardless of the level of the injury, the onset and progression of progressive neurological deterioration are indications for emergency decompression. ${ }^{5}$

\section{MATERIAL AND METHODS}

An observational, retrospective study of the five years from January 1, 2009 to December 2013 was conducted that included 20 patients with a clinical diagnosis of a shotgun wound to the spine. Subsequently, the clinical records were obtained from the archives of the Hospital Central Militar accessing the data base with the parameters established by the investigators, selecting age, sex, status in the Military (military or eligible for benefits), and hierarchy (in case they are military), and the description of the clinical characteristics of the injury, including the vertebral 
segment affected, admission to the urgent care service, and the admission diagnosis. The circumstances under which the injuries occurred, including the vertebral segment affected, the geographical location at the moment of the injury, whether or not a bulletproof vest was used, the caliber of the projectile, and the number of impacts. Data about the hospitalization, such as days in the hospital, the surgical procedures performed, antibiotic therapy and corticosteroid therapy applied, whether transfusions were administered or not, readmissions, complications, and the degree of disability were collected.

The approval by the hospital bioethics committee was dispensed as it was a retrospective study

Subsequently, statistical analysis of the data was performed to create tables, expressing the results graphically, and to formulate conclusions. Finally, a descriptive statistical analysis of skewness and kurtosis, central tendency and dispersion, ratios and proportions was conducted, performing homogeneity tests for the demographic variables and using descriptive statistics for the analysis of the clinical variables.

\section{RESULTS}

We analyzed a total of 20 patients admitted to our hospital between January 1, 2009 and July 2015 with a diagnosis of a wound in the spine from a firearm projectile. Their data were provided by the Statistics Department of this hospital after authorization by the Department of Education and Research. The distribution by year showed a significant increase from 2012 to 2015 , and $75 \%$ of the cases, corresponding to 15 patients, were grouped into this timeframe. (Chart 1) The average age was 27.5 years, with a significant predominance of the group from 21 to 32 years of age. The minimum age was 17 years and the maximum was 37 years of age. (Table 1) The distribution by sex was predominantly male with 19 male patients (95\%) and only 1 female patient (5\%). (Chart 1)

The States of the Republic with the most admissions for GSW were Tamaulipas with 7 patients (35\%), Nuevo León with 3 patients (15\%), and Guerrero with 3 patients (15\%). (Chart 1)

The medical records of all the patents were obtained and the following variables were analyzed:

Status: Most of the patients with GSW were active military personnel (19 patients, 95\%) and there was one other patient eligible for benefits (5\%). (Figure 1) The most affected group was troop members with 18 patients (90\%). One official (5\%) and one patient eligible for benefits (5\%) were also included. (Chart 1 and Figure 2)

Circumstances: Most of the GSWs were received during army activities targeted at reducing violence in the country (15 patients, 75\%), while 4 patients (20\%) were shot in the street and $1(5 \%)$ by a stray bullet. (Chart 1 and Figure 3 )

Caliber: $9 \mathrm{~mm}$ caliber arms accounted for $60 \%, 7.62 \times 39$ for $30 \%$, and $5.56 \times 45$ for $10 \%$ of the wounds. (Table 2) However, in 95\% the bullets were not obtained. (Figure 3, Chart 2)

Number of impacts: The number of impacts received ranged from 1 to 4 with an average of $1.35,17$ patients (85\%) received one impact, 2 patients (10\%) received 2 impacts, 1 patient (5\%) received 4 impacts. (Chart 2) Spinal segment: A total of 25 impacts in 20 patients were recorded, with an average of 1.25 per patient. The most affected segments were the thoracic with 11 impacts (55\%) and the cervical with 5 impacts (25\%), followed by the lumbar segment with 2 impacts (10\%), and the sacral with 2 impacts (10\%). (Table 2) All vertebral segments were affected. (Table 2, Figure 4)

Surgical procedures: A total of 24 surgical procedures were performed during the hospitalization of the patients with GSW over the 7 years of the study, of which surgical cleaning was the most common intervention at 50\% (12 procedures) followed by fixation plus laminectomy at 25\% (6 procedures), and exploratory laparotomy at 8.3\% (2 procedures). (Chart 3, Table 2, Figure 5)

Presence of fracture: $100 \%$ of the patients had some kind of fracture, 7 of them with spinal cord involvement (Chart 2). In this case all 100\% of the fractures were considered to be exposed fractures. (Chart 2) There was spinal cord involvement in $50 \%$ of the patients. (Chart 3 )
Chart 1. List of wounded patients.

\begin{tabular}{|c|c|c|c|c|c|c|}
\hline & Rank & Sex & Year & Age & $\begin{array}{c}\text { Place where } \\
\text { lesion oc- } \\
\text { curred }\end{array}$ & $\begin{array}{l}\text { Situation under } \\
\text { which wound } \\
\text { occurred }\end{array}$ \\
\hline 1 & soldier & male & 2009 & 22 & DF & public street \\
\hline 2 & soldier & male & 2010 & 21 & Tamaulipas & army activities \\
\hline 3 & $\begin{array}{l}\text { second } \\
\text { sergeant }\end{array}$ & male & 2010 & 35 & Michoacan & public street \\
\hline 4 & $\begin{array}{c}\text { army } \\
\text { corporal }\end{array}$ & male & 2011 & 23 & Veracruz & public street \\
\hline 5 & soldier & male & 2011 & 32 & Nuevo Leon & army activities \\
\hline 6 & $\begin{array}{c}\text { army } \\
\text { corporal }\end{array}$ & male & 2012 & 32 & Guerrero & army activities \\
\hline 7 & $\begin{array}{c}\text { army } \\
\text { corporal, } \\
\text { cavalry }\end{array}$ & male & 2012 & 21 & Tamaulipas & army activities \\
\hline 8 & $\begin{array}{l}\text { soldier, } \\
\text { military } \\
\text { police }\end{array}$ & male & 2012 & 28 & Tamaulipas & army activities \\
\hline 9 & dha & female & 2013 & 17 & Guerrero & stray bullet \\
\hline 10 & $\begin{array}{l}\text { second } \\
\text { sergeant, } \\
\text { military } \\
\text { police }\end{array}$ & male & 2013 & 31 & Edo Mex & public street \\
\hline 11 & lieutenant & male & 2013 & 32 & $\begin{array}{c}\text { San Luis } \\
\text { Potosi }\end{array}$ & army activities \\
\hline 12 & soldier & male & 2014 & 28 & Nuevo Leon & army activities \\
\hline 13 & $\begin{array}{c}\text { army } \\
\text { corporal }\end{array}$ & male & 2014 & 28 & Tamaulipas & army activities \\
\hline 14 & $\begin{array}{c}\text { army } \\
\text { corporal, } \\
\text { cavalry }\end{array}$ & male & 2014 & 26 & Tamaulipas & army activities \\
\hline 15 & $\begin{array}{c}\text { army } \\
\text { corporal, } \\
\text { cavalry }\end{array}$ & male & 2014 & 35 & Tamaulipas & army activities \\
\hline 16 & $\begin{array}{c}\text { army } \\
\text { corporal }\end{array}$ & male & 2014 & 23 & Tamaulipas & army activities \\
\hline 17 & $\begin{array}{c}\text { army } \\
\text { corporal, } \\
\text { cavalry }\end{array}$ & male & 2014 & 35 & Edo Mex & army activities \\
\hline 18 & $\begin{array}{c}\text { army } \\
\text { corporal }\end{array}$ & male & 2015 & 23 & Chiapas & army activities \\
\hline 19 & $\begin{array}{c}\text { army } \\
\text { corporal }\end{array}$ & male & 2015 & 35 & Guerrero & army activities \\
\hline 20 & $\begin{array}{c}\text { army } \\
\text { corporal }\end{array}$ & male & 2015 & 23 & Nuevo Leon & army activities \\
\hline
\end{tabular}

Table 1. Distribution by vertebral segment.

\begin{tabular}{c|c|c|c}
\hline $\begin{array}{c}\text { Cervical } \\
\text { segment }\end{array}$ & $\begin{array}{c}\text { Thoracic } \\
\text { segment }\end{array}$ & Lumbar segment & Sacral segment \\
\hline $25 \%$ & $55 \%$ & $10 \%$ & $10 \%$ \\
\hline 5 impacts & 11 impacts & 2 impacts & 2 impacts \\
\hline
\end{tabular}




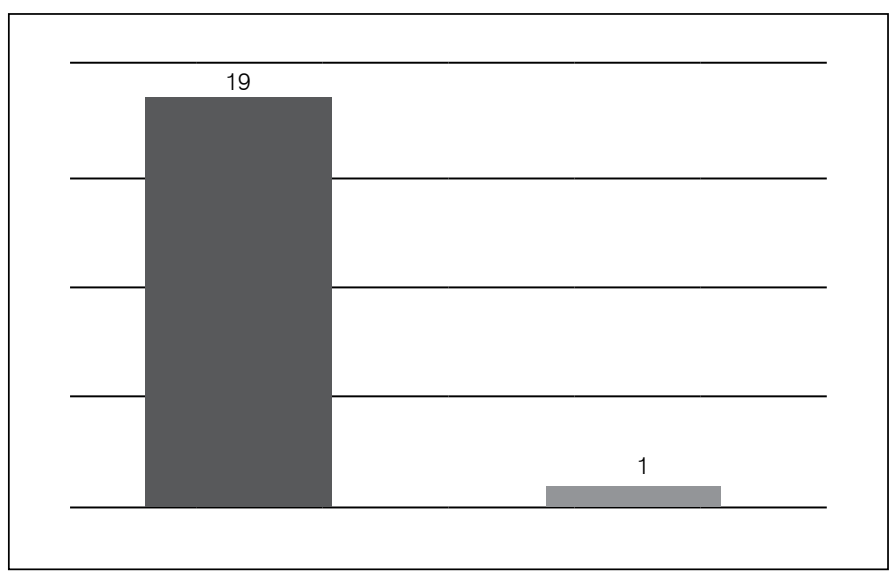

Figure 1. Injured patients: active military (95\%) and eligible for benefits (5\%)

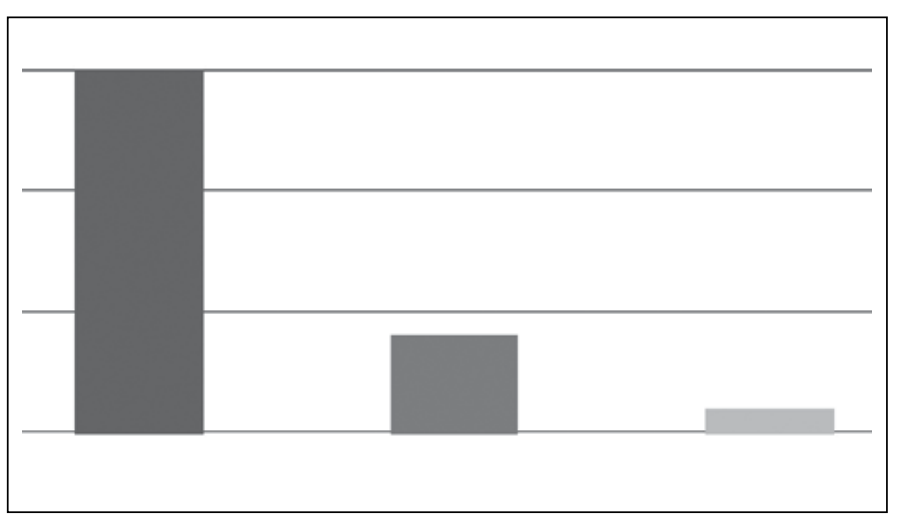

Figure 2. Circumstance during the lesion.
Antibiotic therapy: Antibiotic therapy was administered to 20 patients $(100 \%)$, with ceftriaxone being the most used antibiotic, with a double regime in 10 patients (50\%), mainly of ceftriaxone + clindamycin. The antibiotics were administered for an average of 17.21 days, ranging from 9 to 30 days. (Chart 2)

Corticosteroid therapy: Corticosteroid therapy was not administered to any of the patients with firearm projectile wounds treated in the Hospital Central Militar. (Chart 2)

Blood transfusions: Of the 20 patients, 10 required transfusions of blood products (50\%), 6 of whom received one blood transfusion during their hospitalization, 3 of whom received two transfusions, and 1 patient who received four transfusions to correct hemodynamic management. (Chart 3)

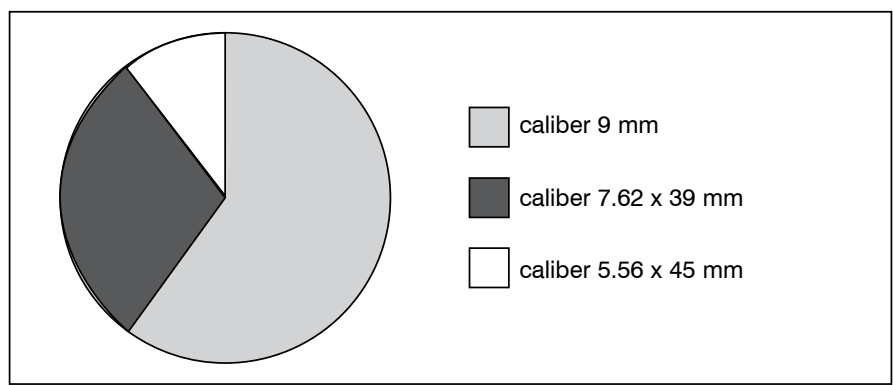

Figure 3. Caliber of the weapon

Table 2. Percentage and distribution of surgical procedures.

\begin{tabular}{c|c|c}
\hline Surgical cleaning & $\begin{array}{c}\text { Fixation plus } \\
\text { laminectomy }\end{array}$ & $\begin{array}{c}\text { Exploratory } \\
\text { laparotomy }\end{array}$ \\
\hline $50 \%$ & $25 \%$ & $8.30 \%$ \\
\hline 12 procedures & 6 procedures & 2 procedures \\
\hline & & Total: 24 procedures \\
\hline
\end{tabular}

Chart 2. List of type of lesion, classification, pharmacological management.

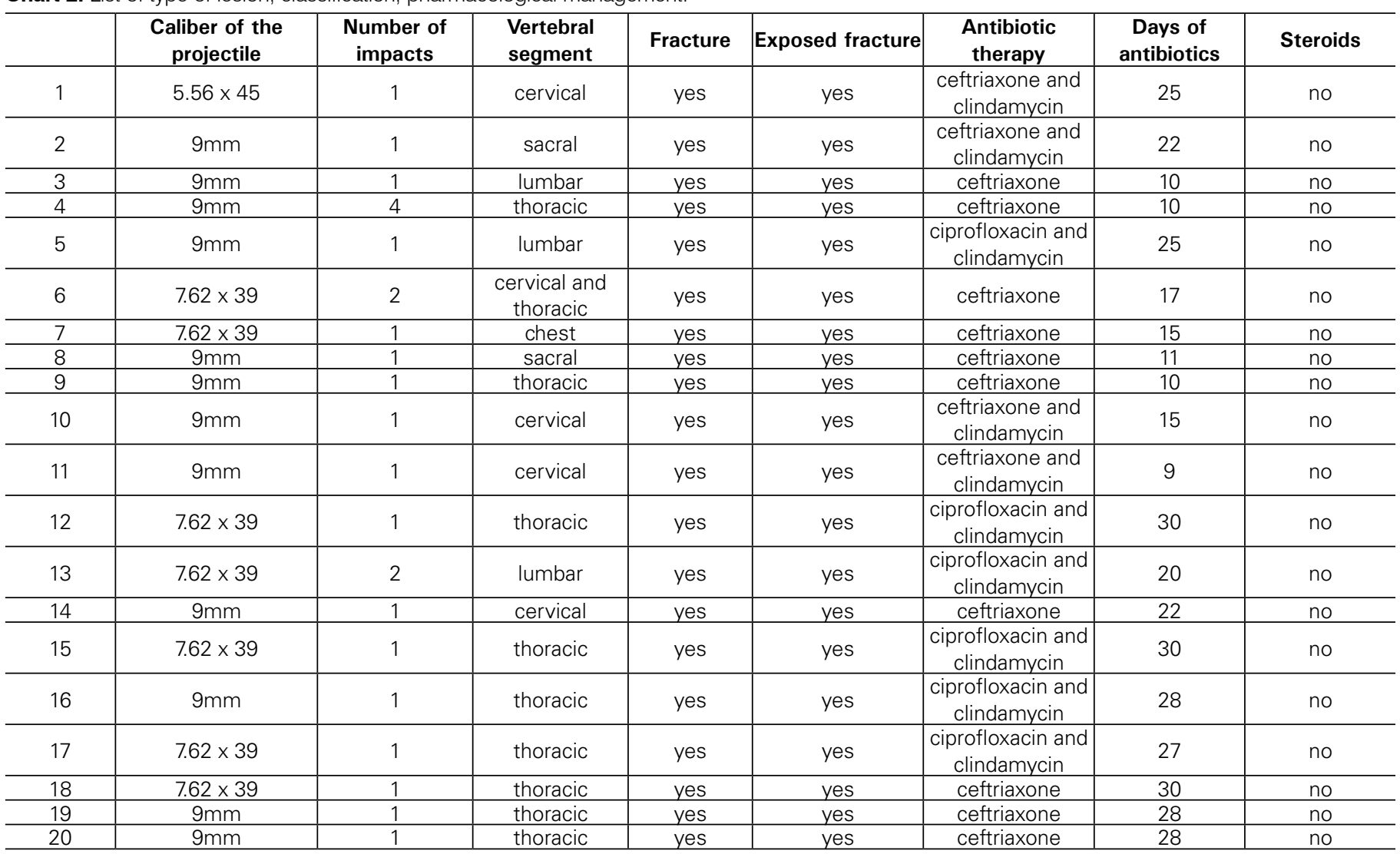


Readmissions: Of the 20 patients included, 50\% (10 patients) had to be readmitted to the hospital to manage the sequelae from gunshot wounds to the spine. (Chart 3)

Disability: Of the 19 active military patients at discharge, 9 (47.3\%) had first category disability, 4 (21.05\%) had second category disability, 1 (5.2\%) had third category, and 5 (26.31\%) had less than $20 \%$ disability. The patient eligible for benefits was excluded from the degree of disability analysis, however. (Chart 3)

Deaths: No deaths were documented among the 20 patients studied, military or eligible to receive benefits, from the attention received or by reason of the current treatment. (Chart 3)

Protection: Use of a vest was another parameter evaluated in the notes and records of the 19 patients in the study. Use of a vest was confirmed in $95 \%$ of the patients. (Figure 6)

Chart 3. List of treatments, sequelae, blood transfusions for injured patients.

\begin{tabular}{c|c|c|c|c|c}
\hline & $\begin{array}{c}\text { Treatment } \\
\text { received }\end{array}$ & Sequelae & $\begin{array}{c}\text { Blood } \\
\text { transfusions }\end{array}$ & $\begin{array}{c}\text { Readmis- } \\
\text { sions }\end{array}$ & Deaths \\
\hline 1 & $\begin{array}{c}\text { Fixation plus } \\
\text { laminectomy }\end{array}$ & Quadriplegia & yes & yes & no \\
\hline 2 & $\begin{array}{c}\text { Exploratory } \\
\text { laparotomy }\end{array}$ & $\begin{array}{c}\text { Low back } \\
\text { pain }\end{array}$ & yes & yes & no \\
\hline 3 & Surg. cleaning & None & no & no & no \\
\hline 4 & Surg. cleaning & $\begin{array}{c}\text { Restrictive } \\
\text { pneumopa- } \\
\text { thy }\end{array}$ & no & no & no \\
\hline 5 & $\begin{array}{c}\text { Exploratory } \\
\text { laparotomy }\end{array}$ & none & yes & yes & no \\
\hline 6 & $\begin{array}{c}\text { Fixation plus } \\
\text { laminectomy }\end{array}$ & Paraplegia & no & no & no \\
\hline 7 & $\begin{array}{c}\text { Fixation plus } \\
\text { laminectomy }\end{array}$ & Paraplegia & no & no & no \\
\hline 8 & Surg. cleaning & none & no & no & no \\
\hline 9 & Surg. cleaning & Paraplegia & no & no & no \\
\hline 10 & Surg. cleaning & none & yes & yes & no \\
\hline 11 & Surg. cleaning & Neck pain & yes & yes & no \\
\hline 12 & $\begin{array}{c}\text { Fixation plus } \\
\text { laminectomy }\end{array}$ & $\begin{array}{c}\text { Neurogenic } \\
\text { bladder, dvt }\end{array}$ & yes & yes & no \\
\hline 13 & Surg. cleaning & Paraplegia & yes & yes & no \\
\hline 14 & Surg. cleaning & Neck pain & no & no & no \\
\hline 15 & $\begin{array}{c}\text { Fixation plus } \\
\text { laminectomy }\end{array}$ & Paraplegia & no & no & no \\
\hline 16 & $\begin{array}{c}\text { Fixation plus } \\
\text { laminectomy }\end{array}$ & Paraplegia & no & no & no \\
\hline 17 & Surg. cleaning & none & no & no & no \\
\hline 18 & Surg. cleaning & Paraplegia & yes & yes & no \\
\hline 19 & Surg. cleaning & none & yes & yes & no \\
\hline 20 & Surg. cleaning & Neck pain & yes & yes & no \\
\hline & & & & \\
\hline
\end{tabular}

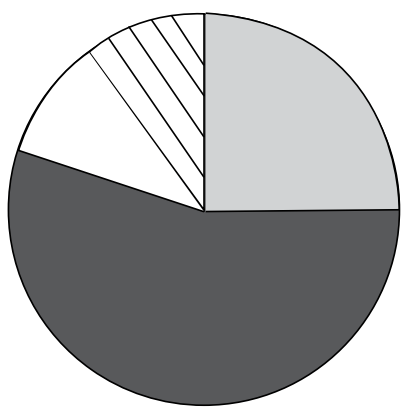

Cervical segment

Thoracic segment

$\square$ Lumbar segment

Sacral segment

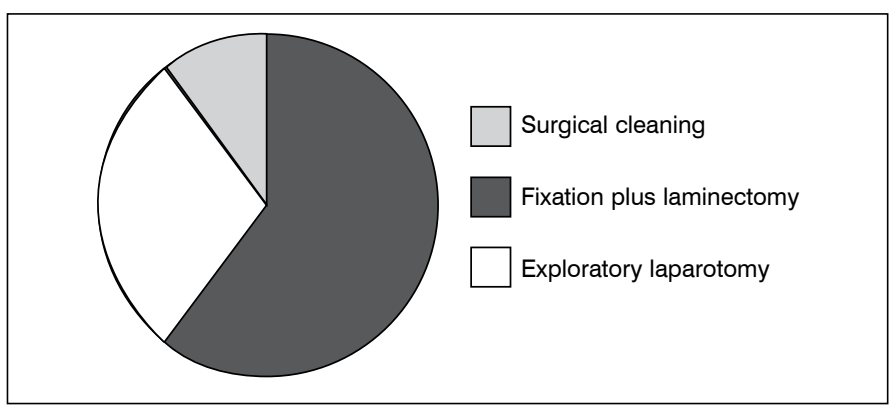

Figure 5. Surgical procedures performed.

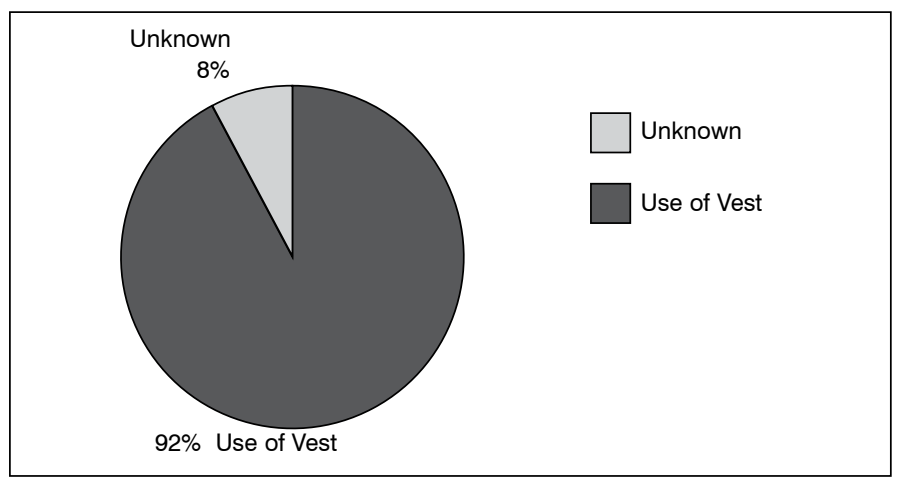

Figure 6: Use of protection.

\section{DISCUSSION}

Gunshot wounds of the spine require high quality medical attention, which is costly due to the medical-surgical and rehabilitation treatments and the treatment of sequelae. In a 4-years study conducted in Ireland by Simón J. Roche, it is estimated that the annual cost of attention to this type of patient is $\$ 9.7$ million. In our study, we did not estimate the costs, but from the number of days in the hospital and of medical-surgical treatment, we estimate that it represents a high cost to our institution. ${ }^{5-8}$ Also, in the same study by Roche, the highest incidence occurs in male patients 20 years of age, while in women there are two peaks at 19 and 76 years of age..$^{6,7}$ In our study, the highest incidence is in the group from 22 to 33 years of age. Our youngest patient was 17 years old and our oldest patent was 37 .

According to B. Splavski, in his study of 21 cases in Croatia, gunshot wounds occur most frequently to the thoracic spine and are commonly associated with abdominal and chest wounds. In this study, these injuries are associated with damage to the abdominal organs in $47 \%$ of the cases. ${ }^{7-9}$ In our study, the most affected level is consistent with that described by Splavski, since in $55 \%$ of the cases (11 patients) there was injury to the thoracic spine. They observed no postoperative neurological recovery in $49 \%$ of the cases and moderate to total recovery in $53 \%$ of the patients. This data are consistent with our results with partial or complete recovery in $50 \%$ of the cases. . $^{8,9}$

A study about control of damage in spinal trauma published in Australia by Thomas Kossmann et al. refers to the controversy around pharmacological treatment with methylprednisolone. ${ }^{8,9}$ In their study they use a regime of methylprednisolone when the evolution time is less than 8 hours after the time of the injury, however, there are multiple studies that have demonstrated that this treatment is of no use (NASCIS III). For this reason, a regime of methylprednisolone is not used for patients with GSWs at this hospital.

The plain radiographs continue to play a crucial role in the evaluation of GSWs of the spine, and in addition to a lateral radiograph of the cervical spine, a projection of the chest and the pelvis are required. All our patients underwent a computed axial tomography (CAT) study. The study by Kossman concludes that CAT offers excellent sensitivity, showing the bone structure of the cervical spine and of the medullary canal. Nuclear magnetic resonance was not

Figure 4. Vertebral segment affected. 
performed for any of our cases because of the presence of metal in the form of bullets or fragments in the vicinity of the spinal cord. ${ }^{10}$ In the retrospective review conducted in New Orleans between January 2007 and November 2011 of a total of 147 patients, the mortality rate was $7 \%$ (10 patients) during hospitalization. One hundred and twenty-seven (87\%) of the patients were treated conservatively. Twenty patients underwent surgery, 13 for lesions below T11 and 7 for lesions above T11. None of the patients who underwent surgery for lesion above T11 showed improvement in their ASIA scores. ${ }^{11,12}$ In our study, 24 surgical procedures were performed on patients with GSW during hospitalization during the 7 years of the study, with surgical cleaning occupying first place among the interventions performed at 59\%, followed by fixation + laminectomy at $25 \%$ and exploratory laparotomy at $12 \%$. In the United States of America, in a study of Wounds from Firearms Projectiles, there were 19 cases of adolescents, with an average age of 17 years, out of a total of 3,150 patients studied..$^{12}$ In our statistics, only one case of a patient younger than 17 years of age was reported.

\section{CONCLUSIONS}

In the Secretariat of National Defense, the Hospital Central Militar offers the highest level of medical attention of the Military Health System, and for this reason, patients requiring high specialty attention are concentrated there.

Due to the social and security situation in our country over the last four years, spinal injuries from firearm projectiles are relatively frequent among the military population. As can be deduced, these are associated with a high level of short-, mid-, and long-term sequelae, great physical disability, prolonged hospitalization time, thus generating very high costs.

It is for this reason that in our hospital a particular interest has been generated in converting it into a production and scientific medical information center focused on gunshot wounds to the spine and war surgery at the national and international levels. This epidemiological review is one of the activities required to establish the foundations of this new knowledge.

The tissue damage that occurs in gunshot wounds is a result of the consecutive effect of the projectile and the cavitation correlated with the kinetic energy. Neurological damage can occur if the projectile passes through or close to the spinal cord.

To approach a study of these injuries, plain radiographs are critical for decision making. Magnetic resonance enables a cataloguing of the anatomical lesion of the spinal cord, as well as the existence of residual compression a nd foreign bodies retained, although there is no standard that correlates to the possibilities of neurological improvement other than a normal spinal cord and the risk of heating the projectile or causing it to migrate, which could cause neurological damage, is always present. Surgical treatment in this hospital for this type of injury is indicated for spinal instability, extraction of a projectile located close to the medullary canal generating residual compression, epidural hematoma causing progressive neurological deficit, and cerebrospinal fluid fistula, and can only change the prognosis when at the lumbar level. Extraction of an interspinal projectile at the cervical and thoracic levels serves to avoid late myelopathy and lead intoxication.

Vertebral lesions from firearm projectiles in the civil population (low velocity) are intrinsically stable lesions and most of them are treated orthotically, unlike high-velocity injuries that usually cause greater spinal bone damage and/or are associated with multisystemic injuries.

In this hospital, surgical approaches are performed in two stages - the first to limit the damage performing an early surgery for decompression of the medullary canal, debridement, and surgical cleaning of the wound, the second to perform stabilization and probably a spinal reconstruction.

The degree of functional recovery in spinal cord lesions from firearm projectiles is lower than in other types of injuries and the outcome of surgical management generally depends on the spinal level involved, the initial neurological level, the trajectory of the projectile, and the time until surgery.

Some cases of cervical injuries with incomplete spinal cord lesions result in functional recovery. The worst functional neurological prognosis comes from lesions of the thoracic spine.

According to the world literature, the opinions of specialists, metaanalysis, and our own experience in this environment, we do not recommend the use of intravenous steroid protocols because there have been no beneficial effects shown and there is even evidence of an increase in mortality in many of the cases. We believe that it is important to decide on early surgical treatment. Spinal injuries are a medical condition with devastating consequences for the patient and his family and can result in dependence on social services indefinitely.

The epidemiological characteristics of spinal injuries from firearm projectiles and the treatment administered to outpatients are comparable to those reported in the national and international literature, of course with some variations in relation to the missions that our user population must meet and of the access that it has to health services.

In Mexico, the medical community dedicated to the management of these injuries needs to be sensitized and encouraged to document case reports in a more precise and systematic manner and to establish a national registration system for spinal lesions in which all the institution of the National Health System participate and a data base in order to understand the impact that these injuries are having on society.

\section{ACKNOWLEDGEMENTS}

We thank the management of the Hospital Central Militar for providing their support in sharing our experiences and promoting research in our study areas and also the civilian personal that assisted us in the publication of this article.

All the authors declare that there are no conflicts of interest regarding this article.

AUTHORS' CONTRIBUTION: AAM prepared the manuscript and statistical analysis. ELB did the statistical analysis. IEHT had the original idea. EAMM and JJAB oversaw the Article

\section{REFERENCES}

1. Tejeda-Barreiras M. Heridas de Arma de Fuego en la Columna Vertebral. Ortho Tips. $2011 ; 7(3-4): 155-61$

2. Bartlett CS. Clinical update: gunshot wound ballistics. Clin Orthop Relat Res. 2003:408:28-57

3. Manzone S, Marcelo SE, Monica K, Mariño E, Manzone P. Lesiones Vertebro-Medulares por Proyectiles de Arma de Fuego en la Población Civil del Chaco. Rev Pos VI Cat Med. 2002:122:21-5

4. Cristiani DG, Beltran R. Lesiones Causadas por Proyectil de Arma de Fuego. Estudio epidemiológico en el Hospital Sharp de Mazatlán, Sinaloa. Acta Ortop Mex. 2004;18(2):37-40.

5. Mannion SJ, Chaloner E. Principles of war surgery. BMJ. 2005;330(7506):1498-500.

6. Dougherty PJ, Vaidya R, Silverton CD, Bartlett C, Najibi S. Joint and long-bone gunshot injuries. J Bone Joint Surg Am. 2009;91(4):980-97.
7. Trahan J, Serban D, Tender GC. Gunshot wounds to the spine in post-Katrina New Orleans Injury. 2013;44(11):1601-6.

8. Paul AD, Koval KJ, Tejwani NC, Egol KA. Gunshot Wounds to the Extremities, Bulletin of the NYU Hospital for Joint Diseases. 2006:64(3-4):139-51.

9. Kitchel SH. Current treatment of gunshot wounds to the spine. Clin Orthop Relat Res 2003;(408):115-9.

10. Lehman RA Jr, Huddleston P, Yaszemski M. Axial spine injuries in the current conflicts in Iraq and Afghanistan. J Am Acad Orthop Surg. 2012;20(Suppl 1):S13-7.

11. Steinmetz MP, Krishnaney AA, McCormick W, Benzel, Edward C. Penetrating Spinal Injuries. Neurosurg Q. 2004;14(4):217-23.

12. Aryan $\mathrm{HE}$, Amar AP, Ozgur BM, Levy ML. Gunshot wounds to the spine in adolescents. Neurosurgery. 2005;57(4):748-52. 